\title{
TESTBED FOR VIRTUAL MICROGRID CONTROL STRATEGY DEVELOPMENT
}

\author{
Dr. Péter Kádár, member of IEEE \\ kadar.peter@kvk.bmf.hu \\ Budapest Tech, Dept. of Power Systems \\ Bécsi u. 94., Budapest \\ H-1034 HUNGARY
}

\begin{abstract}
The Power System Department of the Budapest Tech educates power engineering students and performs research and development activities on power system control area, as well. In 2005-2006 a demonstrational energy park was set up on the roof of the building where the new types of the power generation methods can be investigated in practice. The park contains photovoltaic panel, wind turbine, heat pump, solar collectors and fuel cell.

In the park the students make performance measurements on the individual units. Now we are working on the physical building of the microgrid that will be controlled from a SCADA console.
\end{abstract}

Keywords - Renewable energy, demonstration energy park, education, microgrid, control strategy

\section{OBJECTIVES}

On one hand the renewable energy production gets more and more importance, on the other hand there are a lot of obstacles that slow the wide spread of the small scale units. In this paper we introduce our initiative that supports the education and provides a test bed for the physical integration into the existing grids. The further aim is to characterize the really "Smart Grid".

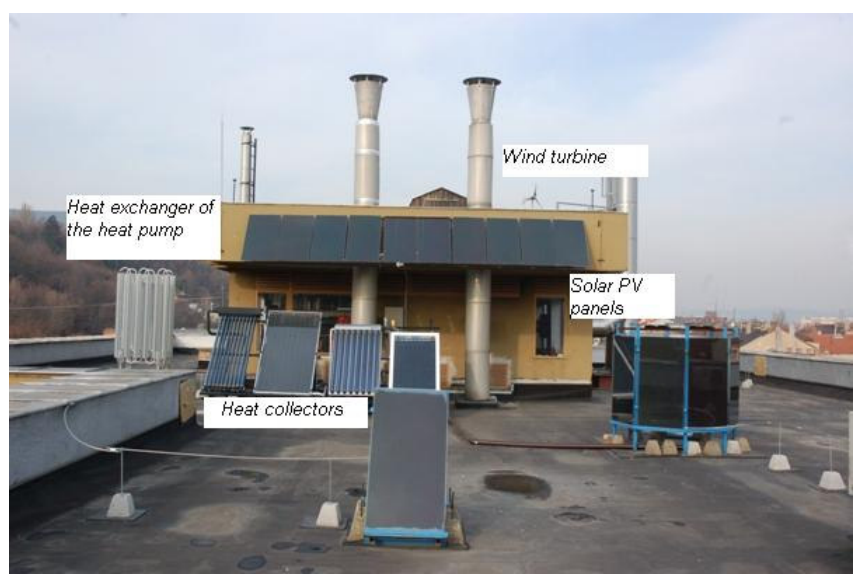

Fig.1.: Renewables on the roof
The energy park has five elements. Four of five are located on the $6^{\text {th }}$ floor of the educational building. These are photovoltaic panels, heat pump, solar collector and the wind turbine. The small scale fuel cell is in the laboratory. Our plan is to enrich the variety of the tested panels.

\section{THE RENEWABLE PARK ON THE ROOF}

A. Photovoltaics, DS 40 panels

- Nominal power: $40 \mathrm{~W}$

- Nominal voltage: $44,8 \mathrm{~V}$

- Nominal current: $900 \mathrm{~mA}$

- Free running voltage: $62,2 \mathrm{~V}$

- $\quad$ SC current: $1150 \mathrm{~mA}$

- $\quad$ area: $0,8 \mathrm{~m}^{2}$

Running investigations are:

- Definition of operational efficiency

- Find the optimal static position angle

- Effects of the dispersed light

- Aging features

- Planning the best mounting accessories

- $\quad$ prepare help tool for the architects to plan more PV application

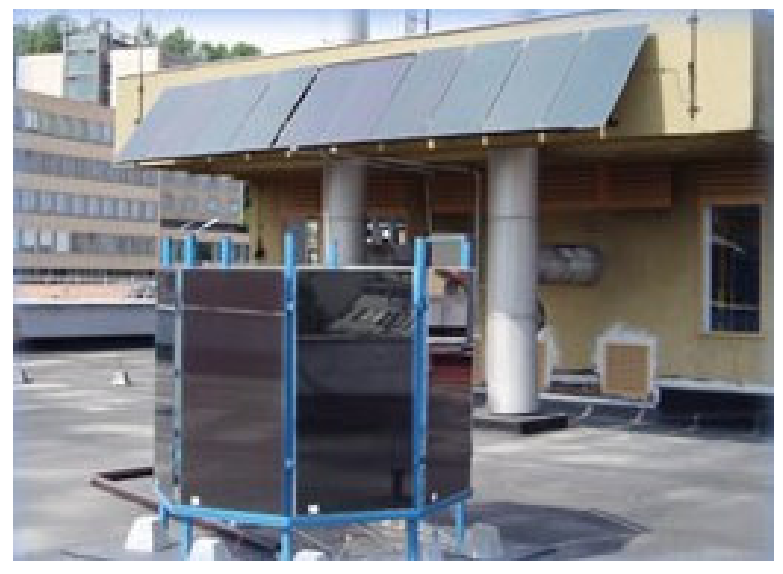

Fig. 2.: The eight-sided Photovoltaic test cube 
Student measurement activities:

- Measurement of panel characteristics

- Inverter characteristics

- Panel positioning

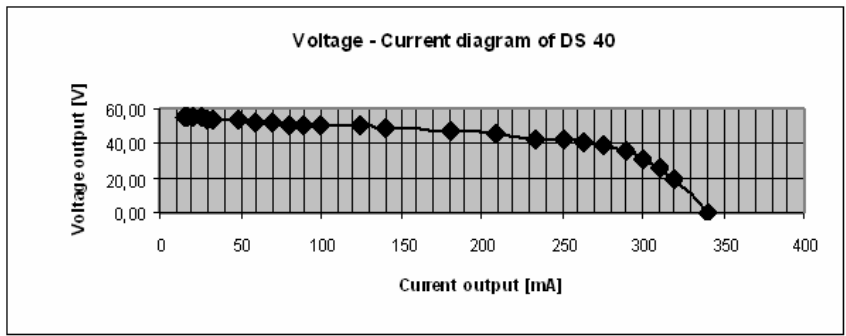

Fig. 3.: Photovoltaic characteristic

Role in the grid:

- weather dependent producer

B. Wind turbine, AIR-X 401

- $\quad$ Rotor diameter: $1,15 \mathrm{~m}$

- Voltage: $12 \mathrm{~V}$

- Cut in speed: $3 \mathrm{~m} / \mathrm{s}$

- Nominal power: $400 \mathrm{~W} / 11,5 \mathrm{~m} / \mathrm{s}$

- Maximal output: $520 \mathrm{~W} / 18 \mathrm{~m} / \mathrm{s}$

- Built in charging controller

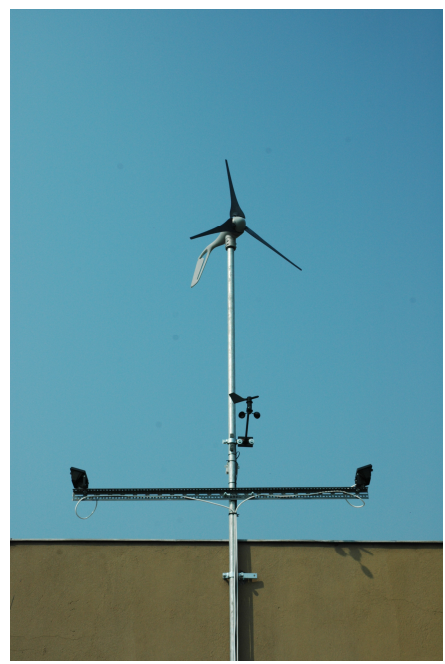

Fig. 4.: The AirX401 wind turbine

Student measurement activities:

- Wind rose, weighted wind rose

- Wind average, turbulence and distribution measurement

- Generator characteristics

Role in the grid:

- weather dependent producer

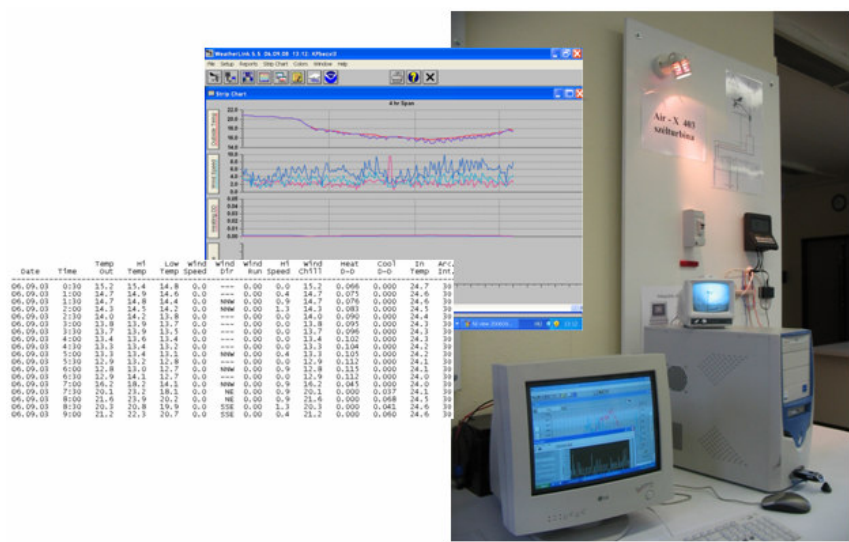

Fig. 5.: Wind measurement "center"

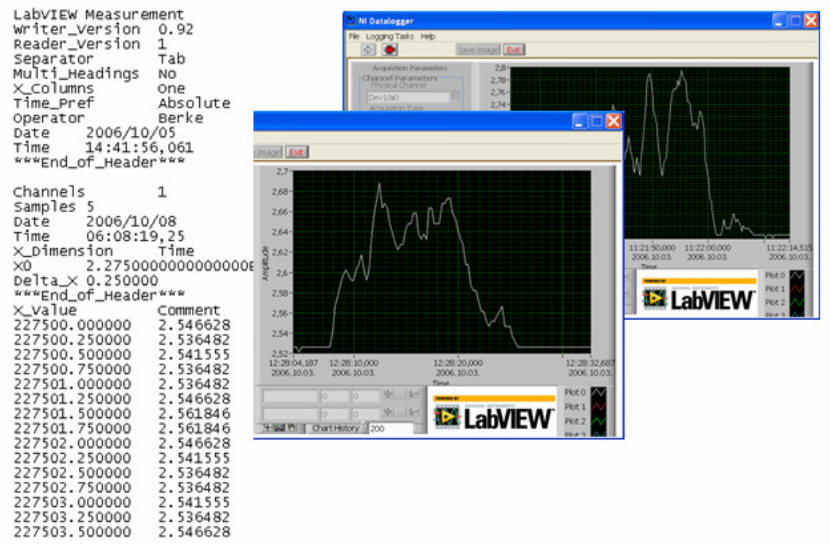

Fig. 6.: Generator current measurements

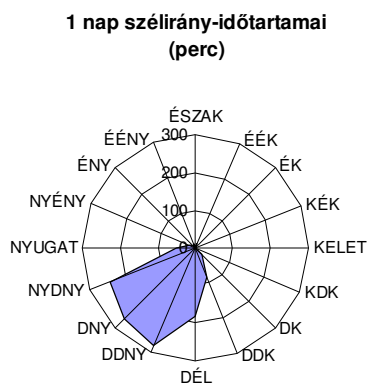

Eloszlás sürüségfüggvény

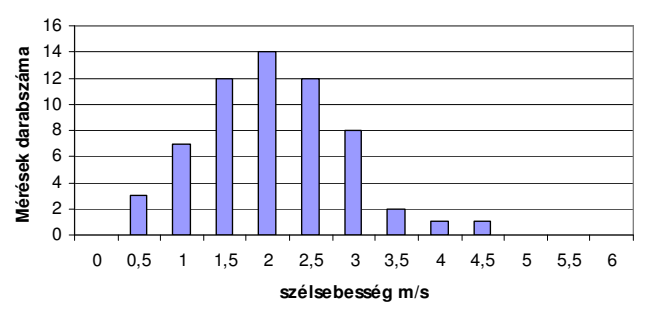

Fig. 7.: Wind rose and distribution 


\section{Fuel cell}

The 20 Watts FLEXIVA fuel cell unit transforms pure hydrogen into electricity. The produced heat is dissipated by air cooling fan. The energy is stored recently in a $12 \mathrm{~V}$ accumulator.

This equipment is capable of independent auto (car) accumulator charging too, but we operate and measure it through a personal computer system.

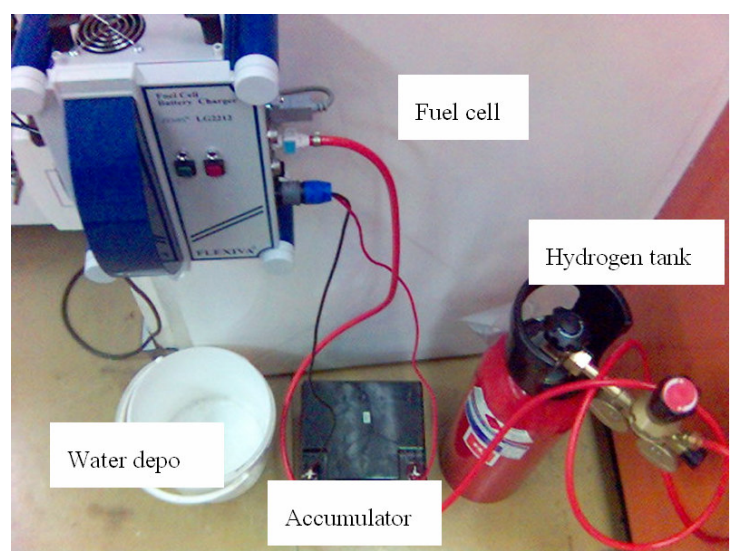

Fig.8.: The fuel cell

Student measurements

- current diagram

- efficiency calculation

- temperature change

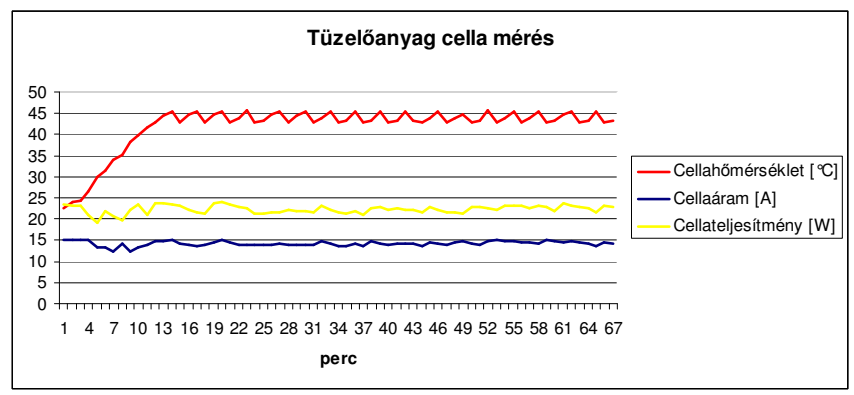

Fig.9.: Temperature and current measurement

Role in the grid

- back-up generator, load balancing, (energy storage in the future)

\section{Heat collector}

The communal energy usage can not be investigated only from the electricity side. The heat consumption has effect on the gas and electricity bills, too, because heating and cooling can run by electricity and gas as well. For the education of the energy consciousness thinking we apply heat collectors, as well. The different types of primary equipment (vacuum tube solar collectors, flat collector and a "hand made" collector) cooperate with the hot water system of the college building. The gas boiler uses the solar preheated water. The measurement system collects the data from the accumulated, stored and used heat. One must mention that the application of the heat collectors seems to be financially the most profitable investment into the renewable.

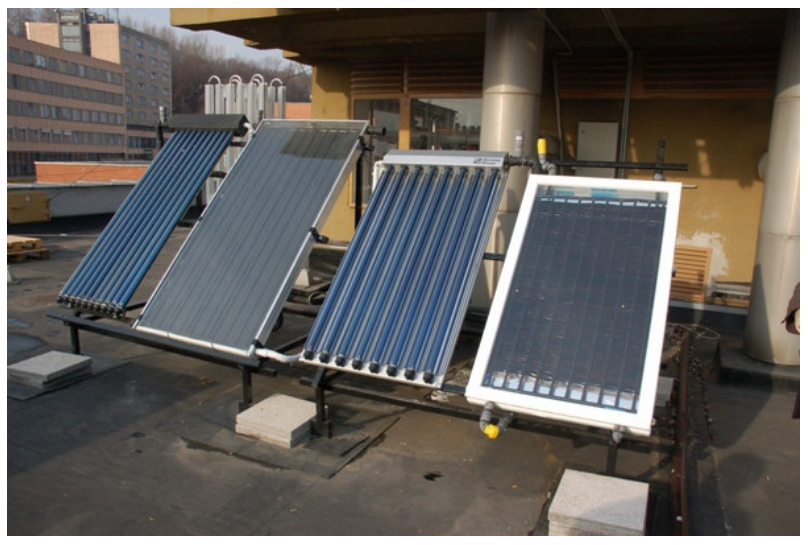

Fig.10.: Flat- and vacuum tube collectors

Student measurements

- efficiency calculation

- heat currents

- temperature change

Role in the grid

- heat producer for the building

\section{E. Heat pump}

One of the most interesting electricalmechanic device with perspective is the heat pump. Recently one $2 / 10$ $\mathrm{kW}$ unit has been set up. Our aim is to perform similar tests like in case of the heat collectors.

Fig.11.: Heat exchanger of the heat pump

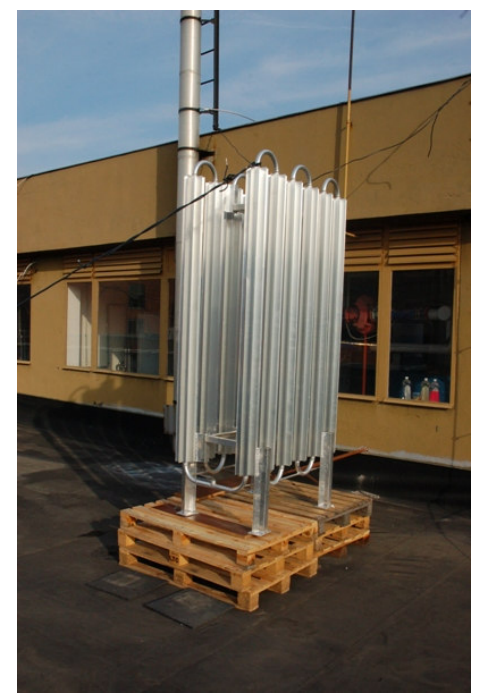




\section{CONTROL AND MEASUREMENT SCENARIOS}

The energy park development is performed according to the next steps:

I. Setting up independent units, with independent measurement systems

II. Unification of the measurement systems

III. Set up a common AC microgrid network

IV. Common load and generation control in the network

V. Set up a virtual microgrid

We plan to feed back to the utility net, too. This is the real test/demonstration of the Distributed Generation in the deregulated market environment.

The PC based control unit is under development. It also controls the load and storage facilities. The PC acts on switches and variable loads.

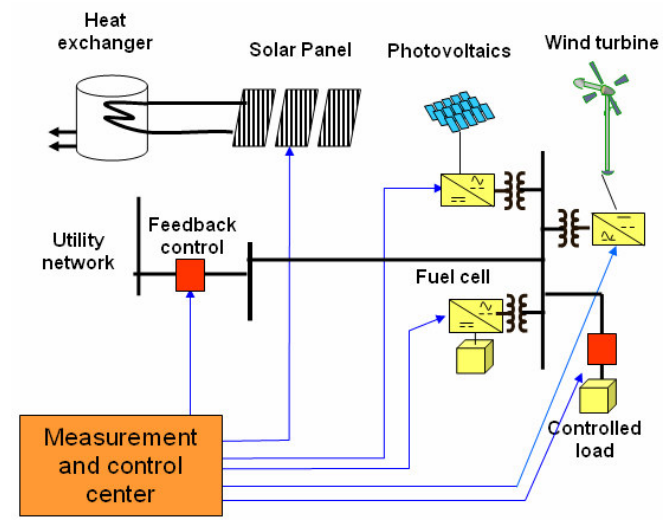

Fig.12.: Setting up the global control system

Further enhancement of the microgrid is the virtual microgrid (smart grid) that requires mainly IT development. In these applications the individual equipments are connected to the normal utility network, but participate in a control system that control specific elements. The control uses the existing Internet infrastructure.

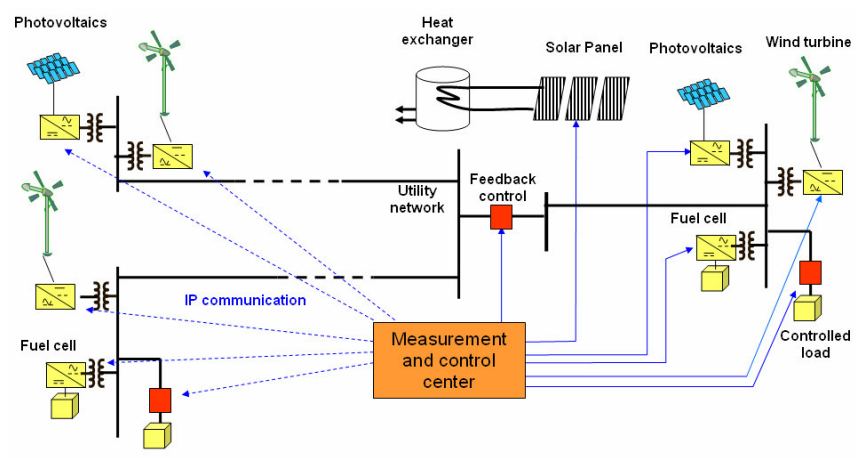

Fig.13.: Virtual Microgrid enhancement

\section{A. Controlling strategies}

After obtaining knowledge about the individual units, complex strategies can be developed regarding the problems and expectations of the main grid's control.

Some problems that encourage our activities:

- The present network control philosophy does not accept with pleasure the small DG and REN units

- The wind power generation creates disturbances

- The cross border transfer capacities are overloaded

- The present DG units gas engines) are uncontrolled, etc.

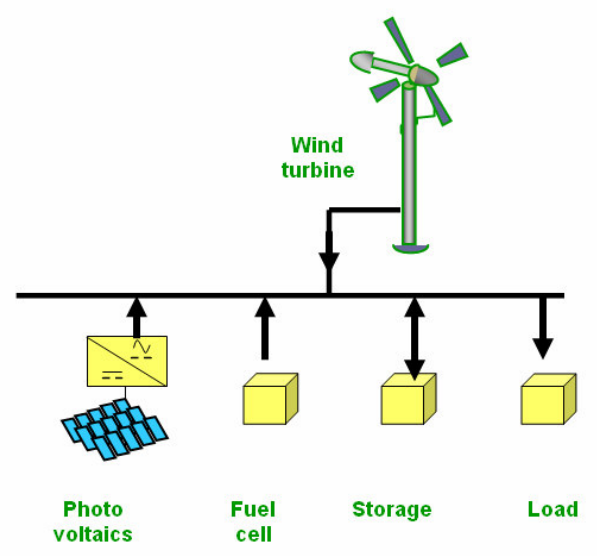

Fig.14.: The islanded renewable system

We develop a control strategy for the islanded system shown in fig.14.:

- The wind power generation strongly depends on the weather. The generation capability can be estimated 24 hours in advance. This generation has priority above the others.

- The photovoltaic generation can be well forecasted, too, but it depends on the coverage factor of the sky.

- The fuel cell has limited output for a long time, but the total generated energy is determined by the amount of the hydrogen fuel.

- The loads can be controlled between limits (this is the DSM - demand side management). Typical load and generation curves (wind, solar, storage and fuel cell) are shown on fig. 15.

Fitting the generation composition to the actual load is a Tetris ${ }^{1}$ problem, where a load curve must be composed by the power of different generator units - at each moment. The applied priorities are: $1^{\text {st }}$ - wind, $2^{\text {nd }}-$ photovoltaics, $3^{\text {rd }}$ Fuel cell (if it is necessary). The surplus energy is used for charging the storage capacity (accumulator). The different units have difference costs, as well. The wind and solar energy are "free", the storage has bad efficiency and limits,

\footnotetext{
${ }^{1}$ Tetris (trademark of The Tetris Company)
} 
the hydrogen based fuel cells are costly and have limited capacity. It is only the emergency reservoir.
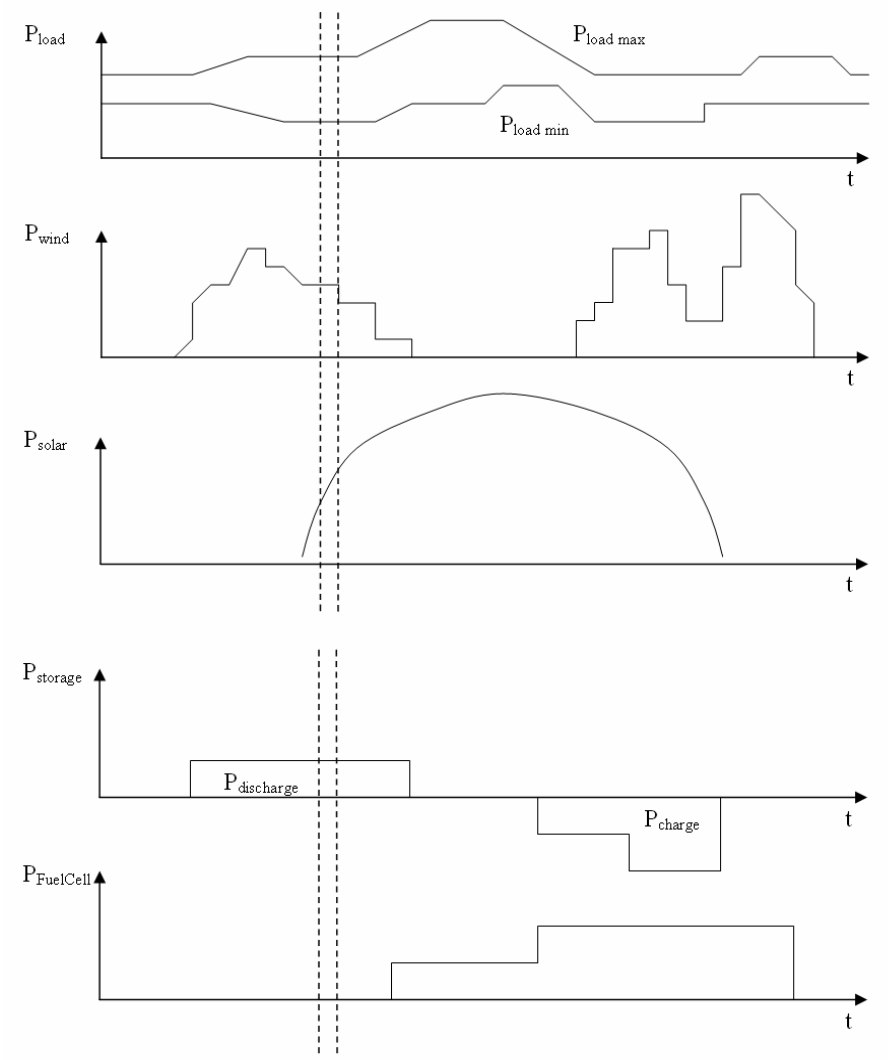

Fig.15.: The load limits and the different generation curves

This continuous constrained portfolio problem is solved by two dimensional linear programming. In the daily schedule the demand and generator curves are sliced for semi steady parts, typically into 5 min. units. In this time window we use the classical linear programming methodologies with constraints.

There are five different operational modes:

1. There is surplus energy to store (see fig. 16.)

2. The primary generation is not enough therefore the accumulator is discharged (only till $40 \%$ ).

3. In case of lack of primary generation (no wind and/or sun shine) the accumulator and the Fuel Cell come into operation (see fig. 17.)

4. In case of lack of stored energy only the Fuel Cell comes into operation

5. In case of unsatisfactory energy generation the load must be shed

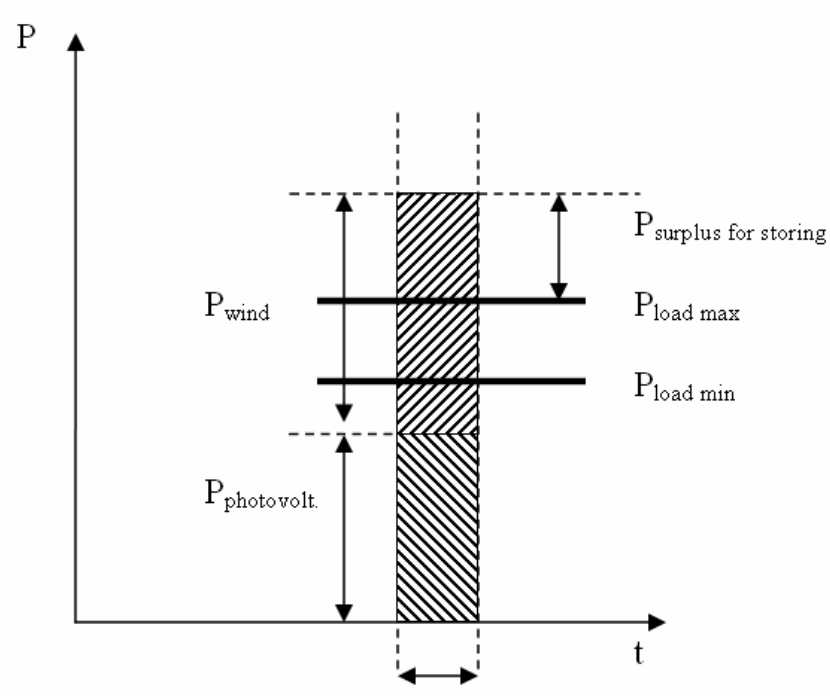

time slice

Fig.16.: Surplus of primary energy

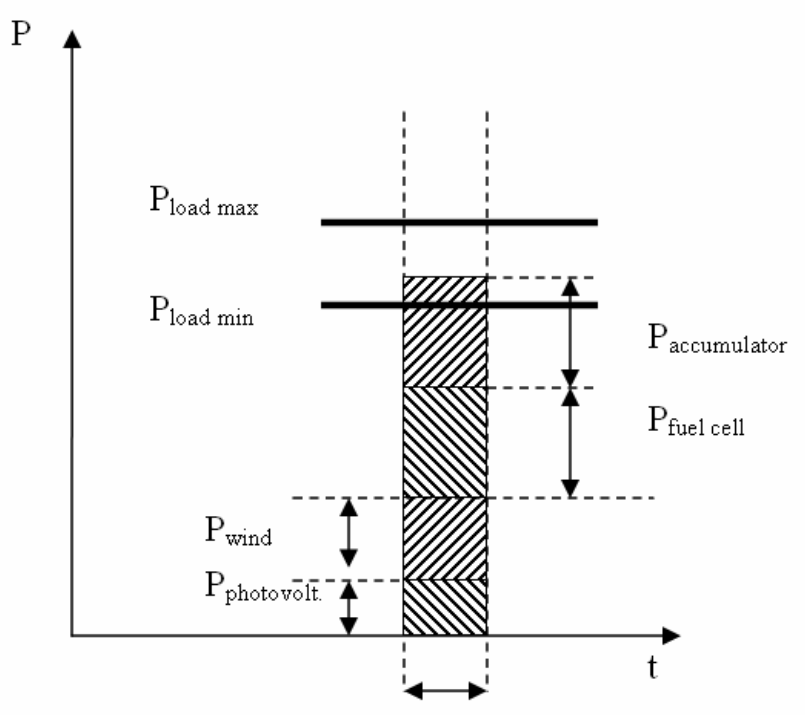

time slice

Fig.17.: The accumulator and the Fuel Cell are in operation

\section{CONCLUSION}

At the Budapest Tech a microgrid development project has been started. Photovoltaic panels, fuel cell, wind turbine, heat pump and solar collector units are installed. With this system different control structures can be investigated. This renewable/distributed energy park is practical education place far beyond the theoretical studies for the coming 
European "SmartGrid" philosophy. Further directions of the research:

- Development of the cooperation control between gas engines and wind turbines

- Development of IP controllable equipments: loads and generator as well

- Preparation of a household controller (maybe on fuzzy base) that optimizes the load schedule.

- Enhancement of the power system's automatic generation control (AGC) with DG control too (beside some great units, hundreds of small equipment could participate in the system), etc.

\section{REFERENCES}

[1] Dr. Péter Kádár: Seeking for the optimal market; $4^{\text {th }}$ Slovakian - Hungarian Joint Symposium on Applied Machine Intelligence Herl'any, Slovakia January 2021, 2006, SAMI proceedings pp 234-246

[2] Dr. Péter Kádár: Energy on the roof $3^{\text {rd }}$ RomanianHungarian Joint Symposium on Applied Computational Intelligence Timisoara, Romania, May 25-26, 2006; SACI Proceedings pp 343-352

[3] P. Kádár: From the windmills to the wind turbines; book in Hungarian, UMK publ. Budapest, 2006

[4] Dr. Kádár Péter: Energiapark a tetőn I.; Elektrotechnika 2006.09., article in Hungarian 